Ataba et al., J. Appl. Biosci. 2020 Toxicity, chemical composition, anti-inflammatory and antioxidant activities of plants used for the treatment of helminth infections in the Kara and central region of Togo.

Journal of Applied Biosciences 156: 16114 - 16131

ISSN 1997-5902

\title{
Toxicity, chemical composition, anti-inflammatory and antioxidant activities of plants used for the treatment of helminth infections in the Kara and Central region of Togo.
}

Essoham ATABA 1 , Gnatoulma KATAWA 1 , Gerard A. TOUDJI1, Manuel RITTER², Adjoa Holali AMEYAPOH $^{1}$, Pélagie Edlom TCHADIÉ 1 , Komlan BATAWILA ${ }^{3}$, Tchadjabo TCHACONDO ${ }^{1}$, Yaovi AMEYAPOH $^{1}$, Achim HOERAUF 2,4 , Laura E. LAYLAND 2,4 , Simplice D. KAROU ${ }^{1 *}$

${ }^{1} E$ cole Supérieure des Techniques Biologiques et Alimentaires (ESTBA)/Laboratoire de Microbiologie et de Contrôle de Qualité des Denrées Alimentaires/Unité de Recherche en Immunologie et Immunomodulation (UR2IM), Université de Lomé, Togo;

2Institute for Medical Microbiology, Immunology and Parasitology (IMMIP), University Hospital Bonn, Bonn, Germany̌Laboratoire de Biologie et Écologie Végétale, Faculté des Sciences (FDS), Université de Lomé; ${ }^{4}$ German Centre for Infection Research (DZIF), partner site, Bonn-Cologne, Bonn, Germany.

${ }^{* *}$ Corresponding Author: Prof. KAROU D. Simplice,

"'"1Ecole Supérieure des Techniques Biologiques et Alimentaires (ESTBA)/Laboratoire de Microbiologie et de Contrôle de Qualité des Denrées Alimentaires/Unité de Recherche en Immunologie et Immunomodulation (UR2IM), Université de Lomé, BP 1515, Lomé, Togo. Tel: 0022890701925; E-mail: simplicekarou@hotmail.com

Original submitted in on 14th October 2020. Published online at www.m.elewa.org/journals/ on 31st December 2020 https://doi.org/10.35759/JABs.156.5

\begin{abstract}
Objectives: Traditional healers (THs) from the Central and Kara regions of Togo use Aframomum melegueta(Alligator pipper), Khaya senegalensis (Senegal mahogany) and Xylopia aethiopica (Kani pepper) for the treatment of helminths infections. We previously confirmed the anthelmintic effects of these plants. THs had little information about plants compounds, anti-inflammatory, antioxidant activities and toxicity. The present study aimed to investigate antiinflammatory, antioxidant activities and toxicity of Aframomum melegueta, Khaya senegalensis and Xylopia aethiopica used for the treatment of helminthiasis in the Central and Kara regions of Togo.

Methodology and Results: Anti-inflammatory activity was evaluated using the inhibition method of lipoxygenase type IB extracted from soybean. The concentrations of polyphenols and flavonoids were measured respectively by the FolinCiocalteu reagent reduction method and the Aluminium chloride colorimetric method. Antioxidant activity was assessed by the DPPH and ABTS assays. Acute and subchronic toxicity was performed on Wistar rats according to OECD recommendations. Khaya senegalensis and Xylopia aethiopica showed, a greater anti-inflammatory activity by inhibiting lipoxygenase activity in vitro and antioxidant activity (Aframomum melegueta; ABTS $32.79 \pm 3.79$ mgEAA/100mg and Xylopia aethiopica; DPPH IC 50 of $2278.89 \pm 104.68 \mu \mathrm{g} / \mathrm{mL})$. Khaya senegalensis contained a high concentration of flavonoids $(1.39 \pm 0.07 \mathrm{mgEQ} / 100 \mathrm{mg})$ and phenols $(329.21 \pm 19.99 \mathrm{mgEGA} / 100 \mathrm{mg})$. No toxic effects were observed for the chosen doses with these plants extract.

Conclusions and application of findings: Extracts of Khaya senegalensis and Xylopia aethiopica had anti-inflammatory activities. In addition, extracts of Khaya senegalensis and Aframomum meleguetahad excellent antioxidant power and had the highest concentrations of polyphenols and flavonoids. This finding could justify the traditional use of these plant
\end{abstract}


organ extracts for the treatment of helminth infections and provide scientific evidence to traditional healers in the central region and Kara in Togo. However, further studies are necessary to determine the molecules responsible for the pharmacological properties of these plant organ extracts and their mechanisms of action.

Key words: Aframomun melegueta, Khaya senegalensis, Xylopia aethiopica, anti-inflammatory activity, antioxidant activity.

\section{INTRODUCTION}

The use of plants for health care is a matter of culture and tradition in Africa (Jouad et al., 2001; Kokou et al., 2001). It is noted that for primary health needs, a large part of the African population uses traditional medicine, whose remedies are mainly herbal (Karou et al., 2011; Tchacondo, 2011; WHO, 2012). Medicinal plants continue to provide evidence of a very effective remedy against diseases, particularly helminthiasis (Ataba et al., 2020). Aframomum meleguetaseeds are used in Africa to control diarrhoea and gastroenteritis (Jiofack et al., 2008). Xylopia aethiopica was mainly used for healing lymphatic filariasis, schistosomiasis (Oloyede and Aduramigba-Modupe, 2011). Xylopia aethiopica is commonly used in Nigeria to treat parasitic gastrointestinal helminths (Suleiman et al., 2005). Ademola et al. suggested the use of Khaya senegalensis extract in anthelmintic therapy in veterinary practice (Ademola et al., 2004). The anti-trypanosomal activity of Khaya senegalensis has also been studied by some authors (Ibrahim et al., 2013). We recently showed that

\section{MATERIALS AND METHODS}

Experimental animals: Male $(170 \mathrm{~g}-210 \mathrm{~g})$ and female $(150 \mathrm{~g}-185 \mathrm{~g})$ Wistar strain albino rats "Rattus norvegicus" aged approximately 4 months were used for acute and subchronic toxicity. Females were neither pregnant nor lactating. The breeding of these animals took place in the LAMICODA animal house of the University of Lomé. The animals were subjected to natural day and night alternation corresponding to $12 \pm 1$ $\mathrm{h}$ of day and night. They had free access to water ad libitum and feed fed with rodent standard diets. The experimental protocols were guided by the OECD guideline for the care and use of laboratory animals (OCDE, 2001, OCDE, 2009 ).
Aframomun melegueta, Khaya senegalensis, Xylopia aethiopica are the main plants used by traditional healers to treat helminths infections in the Central and Kara regions of Togo and this was interestingly demonstrated and confirmed that these plants had anthelminthic effects in vitro (Ataba et al., 2020). Hyperreactive onchocerciasis was associated with higher inflammatory Th17 responses (Hoerauf et al., 2003; Taylor et al., 2010; Katawa et al., 2015). Many plants have shown anti-inflammatory and antioxidant activities that could contribute to treat helminths induced disorder like skin inflammation and elephantiasis (Hoerauf, 2008; Hoerauf et al., 2011; Ritter et al., 2017). The traditional healers in the study had little information about plants bioactivities, compounds and toxicity. This study was undertaken to investigate on toxicity, compounds, antiinflammatory and antioxidant activities of the main plants used by the traditional healers from the Central and Kara regions of Togo for the treatment of helminths infections.

Plants material: Following an ethnobotanical survey, three plant organs were selected because of their use by THs for the treatment of helminths infections in the Kara and Central regions of Togo. These were trunk bark of Khaya senegalensis harvested in the forest of Tchavadè (central region of Togo), grains of Aframomum meleguetaand fruits of Xylopia aethiopica bought fresh on the market (Figure 1). These extracts are washed and air-dried at laboratory temperature $\left(18\right.$ and $\left.25^{\circ} \mathrm{C}\right)$ and then crushed. From the powders obtained, a hydroethanolic extraction was prepared. Then different concentrations were obtained with distilled water and filtered using a $0.45 \mu \mathrm{m}$ millipore membrane. 
Ataba et al., J. Appl. Biosci. 2020 Toxicity, chemical composition, anti-inflammatory and antioxidant activities of plants used for the treatment of helminth infections in the Kara and central region of Togo.

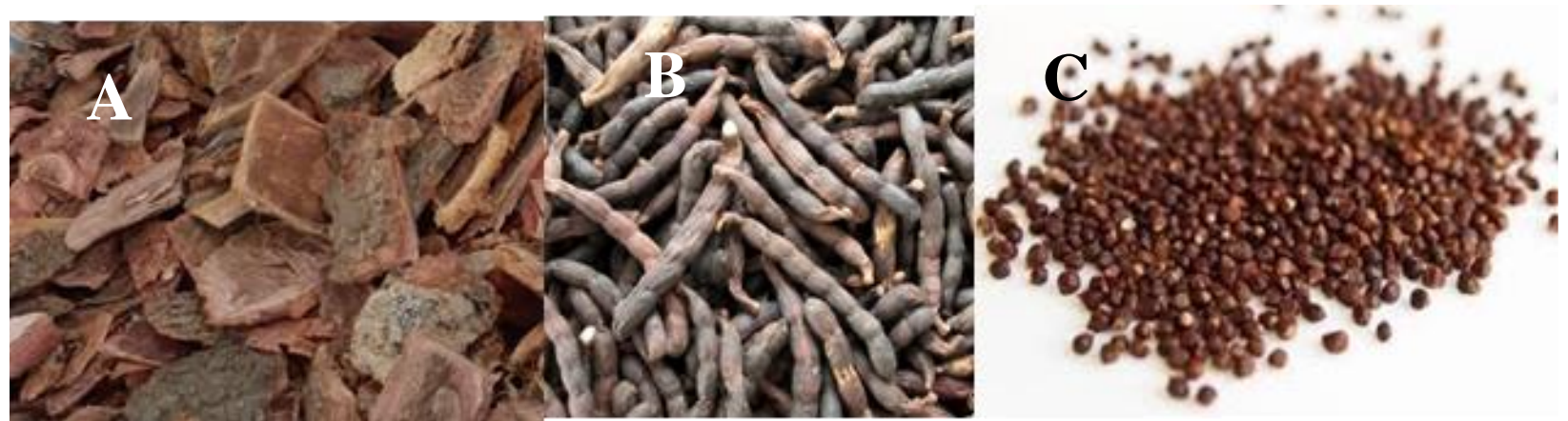

Figure 1: Plants organs. (A) Trunk bark of Khaya senegalensis ; (B) Fruits of Xylopia aethiopica; (C) Grains of Aframomum melegueta

Chemicals and reagents: Borate buffer, Lipoxygenase type I-B, Linoleic acid, quercetin, gallic acid, FolinCiocalteu (FCR), Sodium Carbonate Solution, Aluminium Chloride $\left(\mathrm{AlCl}_{3}\right)$, Methanol, 2, 2-diphenyl-1picrylhydrazyl (DPPH), 2,2'-azino-bis-3ethylbenzthiazoline-6-sulphonic acid (ABTS), Potassium persulfate and Ethanol were purchased from Sigma Aldrich (Spruce, St Louis, Germany). Tryptone Salt solution, Plate Count Agar (PCA), Crystal Violet Agar, Neutral Red Bile Lactose (NRBL) and Sabouraud + Chloramphenicol was supplied by Oxid (Basingtoke, Hampshire, England).

Microbiological quality control: In order to evaluate the microbiological quality of plant extracts, $1 / 10$ dilution was prepared by adding $1 \mathrm{ml}$ of each hydroethanolic extract in $9 \mathrm{ml}$ of Tryptone Salt solution. This was based on the standardized methods of the "Association Française de Normalisation" (AFNOR) and adopted within the WAEMU countries: Order of December 21, 1979 (AFNOR, 2009). The mass seeding technic was adopted for the research of mesophilic aerobic flora on PCA medium at $30^{\circ} \mathrm{C}$ for 72 hours (Reference Method NF V08-051 February 1999). Total coliforms were researched on $\mathrm{NRBL}$ at $30^{\circ} \mathrm{C}$ for 24 hours (reference method NF V08-050 1999); Sabouraud + Chloramphenicol medium were sown and incubated at $30^{\circ} \mathrm{C}$ during 72 hours (NF ISO7954 1988) for moulds and yeasts. The results were then interpreted according to the criteria of the AFNOR standards adopted for Traditional Improved Medicines (AFNOR, 2009).

In vitro anti-inflammatory activity: The in vitro antiinflammatory activity of these plant extracts was evaluated using the inhibition method of lipoxygenase type I-B extracted from soybean. Enzyme solution $(146 \mu l)$ prepared in borate buffer $(0.2 \mathrm{M}$; $\mathrm{pH} 9.0)$ was mixed with $3.7 \mu \mathrm{l}$ of sample at the final concentration of $98.83 \mu \mathrm{g} / \mathrm{mL}$ of extracts. The reaction was then triggered by the addition of $150 \mu \mathrm{L}$ of substrate (linoleic acid of final concentration $1.25 \mathrm{mM}$ ) and the optical density was recorded at $234 \mathrm{~nm}$ with a spectrophotometer (EPOCH 251465, Biotek instruments USA Micro well plate Reader). Borate buffer and enzyme were used as negative controls, substrate and enzyme as positive controls, quercetin and gallic acid at $10 \mu \mathrm{g} / \mathrm{mL}$ were used as reference anti-inflammatory molecules. The test was triplicate under the same conditions. The lipoxygenase inhibition percentage $(\% \mathrm{l})$ was calculated at $1^{\text {st }}, 5^{\text {th }}$ and $10^{\text {th }}$ time according to the following equation:

$$
\% I=\frac{\text { Control OD }- \text { Sample OD }}{\text { Control OD }} \times 100
$$

Control OD = enzyme activity in the absence of samples;

Sample OD = activity of the enzyme in the presence of samples.

Phyotochemical screening and antioxidant activity of Aframomum melegueta, Khaya senegalensis and Xylopia aethiopica

Phytochemical screening.

Total phenolic contents determination : Polyphenols were quantified according to the protocol described by Singleton et al., (Singleton et al., 1999). $25 \mu \mathrm{L}$ of the extract $(0.1 \mathrm{mg} / \mathrm{ml})$ were incubated with $125 \mu \mathrm{L}$ of FolinCiocalteu (FCR, company, country and city) solution $(0.2 \mathrm{~N})$ in 96 -well plate at room temperature for $5 \mathrm{~min}$. Thereafter, $100 \mu \mathrm{L}$ of Sodium Carbonate Solution $(75 \mathrm{~g} / \mathrm{l})$ were added. The absorbances were read at $760 \mathrm{~nm}$ with a spectrophotometer (EPOCH 251465, Biotek instruments USA Micro well plate Reader) after one hour of incubation. The concentrations of phenols in milligrams of gallic acid equivalent (EGA)/100mg extract were calculated according to the formula

$\mathbf{C}=(\mathbf{C l} \times \mathbf{V f}) /(\mathbf{C i} \times \mathbf{V i}) \times \mathbf{1 0 0}$

$\mathrm{C}$ : concentration of the component; $\mathrm{Cl}$ : concentration of final dilution of standard; Ci: initial concentration of the test sample; 

used for the treatment of helminth infections in the Kara and central region of Togo.

Vi: initial volume of the test sample; Vf : final volume in the well containing the test sample.

Total Flavonoids Contents determination : The flavonoids of the plant extracts were determined by the colorimetric method of $\mathrm{AlCl}_{3}$ described by Dowd and adapted by Arvouet-Grand et al., (Arvouet-Grand et al., 1994). This method is based on the absorption capacity at $415 \mathrm{~nm}$ of the aluminium-flavonoid complex formed during the reaction. For this purpose, $100 \mu \mathrm{L}$ of each extract diluted in $1 \mathrm{mg} / \mathrm{ml}$ of methanol was added to $100 \mu \mathrm{L}$ of a $2 \% \mathrm{AlCl}_{3}$ methanolic solution in the wells of a 96-well plate. The flavonoids concentration in milligrams of quercetin equivalent $(E Q) / 100 \mathrm{mg}$ extract were calculated according to the previous formula:

\section{$\mathbf{C}=(\mathrm{Cl} \times \mathbf{V f}) /(\mathbf{C i} \times \mathbf{V i}) \times \mathbf{1 0 0}$}

Antioxidant activities by DPPH radical scavenging activity: The antioxidant activity of the extracts was assessed through their capacity of scavenging stable radicals 2, 2-diphenyl-1-picrylhydrazyl (DPPH). This activity was determined using the stable radical DPPH, according Velázquez et al. (2003) and Toudji et al. (2018) methods. Indeed, the DPPH test consists of the reduction of absorbance at $517 \mathrm{~nm}$ due to the stable free radical DPPH $\bullet$ in the presence of a donor of the radical $\mathrm{H} \bullet$. The assay was performed in triplicate using 96-well plates (Nalge Nunc International, NY, USA). Serial dilution aliquots were made from extracts in solution (10 $\mathrm{mg} / \mathrm{mL}$ ) in methanol by mixing $100 \mu \mathrm{L}$ of each sample with $200 \mu \mathrm{L}$ of DPPH $(20 \mathrm{mg} / \mathrm{L})$. After 15 min of incubation in darkness at room temperature, the resultant absorbance was measured at $517 \mathrm{~nm}$ with a spectrophotometer (EPOCH 251465, Biotek instruments USA Micro well plate Reader) against a blank well with $100 \mu \mathrm{L}$ methanol and 200 $\mu \mathrm{L}$ of DPPH. Quercetin and Gallic acid were used as reference products. The percentage of inhibition was calculated according to the equation:

$$
\mathbf{I} \%=\frac{\mathbf{A 0}-\mathbf{A E}}{\mathbf{A 0}} \times \mathbf{1 0 0}
$$

A0: Absorbance of the blank; $\mathbf{A E}$ : Absorbance of the sample. ABTS radical scavenging assay: Free radical scavenging activity of plant samples was determined by 2,2'-azino-bis-3-ethylbenzthiazoline-6-sulphonic acid (ABTS) radical cation decolorization assay (Re et al., 1999). ABTS + cation radical was produced by the reaction between $7 \mathrm{mM} \mathrm{ABTS}$ in water and $2.45 \mathrm{mM}$ Potassium persulfate (1:1), stored in the dark at room temperature for 12-16 hours before use. Discoloration is monitored by measuring absorbance at $734 \mathrm{~nm}$. Then, $37.7 \mathrm{mg}$ of ABTS is dissolved in $9.802 \mathrm{~mL}$ of distilled water to which $6.48 \mathrm{mg}$ of Potassium persulfate is added. The mixture was homogenized and stored in the dark at room temperature for 12 hours. It was then diluted in ethanol to an absorbance of approximately $0.70 \pm 0.02$ at $734 \mathrm{~nm}$. The free radical capture percentage (1\%) was determined using the following formula:

$$
\mathbf{I} \%=\frac{\mathbf{A 0}-\mathbf{A E}}{\mathbf{A 0}} \times \mathbf{1 0 0}
$$

A0: Absorbance of the blank; AE: Absorbance of the sample. In vivo evaluation of plant extracts toxicity

Acute toxicity.: Acute toxicity was conducted by intragastric tube gavage on male rats according to OECD recommendations (OCDE, 2001). For this study, rats were divided into 4 batches of 3 rats. The first three batches took respectively the hydroethanolic extract of Aframomum melegueta, Khaya senegalensis and Xylopia aethiopica in a single dose of $5000 \mathrm{mg} / \mathrm{Kg} \mathrm{bw}$. The control batch was treated with a saline solution $(\mathrm{NaCl} 9 \%$ ). This solution was used to prepare the different concentrations of the aqueous extract. The animals were observed regularly for 3 hours for 24 hours and then every 6 hours up to 48 hours after dosing to note any changes in their behaviour (Bürger et al., 2005; Ogbonnia et al., 2008). Observations focused on mobility, noise and pinch sensitivity, feeding, breathing, and faeces appearance (Lienou et al., 2007).

Subchronic toxicity: According of the OECD recommendations, the doses of 100 and $300 \mathrm{mg} / \mathrm{Kg} \mathrm{bw}$ were considered for the achievement of subchronic toxicity. The rats were divided into 4 batches of 8 animals each (4 males and 4 females). Three batches received daily doses of 100 and $300 \mathrm{mg} / \mathrm{Kg}$ bw hydroethanolic extracts of Aframomum melegueta, Khaya senegalensis and Xylopia aethiopica for 28 days. The control lot $\left(4^{\text {th }}\right.$ lot) was treated with $\mathrm{NaCl} 9 \%$ over the same period. The behaviour of the rats was observed on a daily basis. The animals were sacrificed at the end of treatment, according to OECD recommendations (OCDE, 2009 ). The blood of each animal was collected both in a tube containing an anticoagulant (EDTA) for blood formula count with the Sysmex XN550 automated system (Sysmex, Paris, France). After centrifugation of the Tubes without anticoagulant, sera obtained were used to determine blood glucose levels, uraemia, creatininaemia, alanine aminotransferase (ALT), aspartate aminotransferase (AST) and alkaline phosphatase (PAL) according to the instructions of the kits (Labkit, Eu-gen) on a DIRUI DR-7000D spectrophotometer (Dirui, Tozkoparan Mah, Gungoren, Istanbul) and as performed by Toudji et al.(Toudji et al., 2017 ). 
Ataba et al., J. Appl. Biosci. 2020 Toxicity, chemical composition, anti-inflammatory and antioxidant activities of plants used for the treatment of helminth infections in the Kara and central region of Togo.

Statistical analysis: The statistical analysis was performed using GraphPad Prism 5.2 software. The values are presented as mean \pm standard error. Significance levels between treated and control batches

\section{RESULTS}

In vitro Anti-inflammatory activity: The extracts of Khaya senegalensis and Xylopia aethiopica have an interesting anti-inflammatory activity showed by their were measured by the $U$ test of Mann Whitney. If $p<0.05$, the difference between the values is considered significant.

capacity to inhibit lipoxygenase activities respectively of $70.28 \%$ and $65.22 \%$ compared to the reference molecules while Aframomum meleguetadoes not exceed $35 \%$ (Table 1).

Table 1: Lipoxygenase inhibition by Aframomum melegueta, Khaya senegalensis and Xylopia aethiopica plant extract.

\begin{tabular}{|c|c|c|c|c|c|}
\hline Time & Qur & Acg & AM & KS & XA \\
\hline $1^{\text {st }} \mathrm{min}$ & $52.04 \pm 2.45$ & $63.66 \pm 2.67$ & $34.53 \pm 0.50$ & $70.28 \pm 3.55$ & $65.22 \pm 1.63$ \\
\hline $5^{\text {th }}$ min & & $1.39 \pm 0.39$ & $25.52 \pm 1.39$ & $92.34 \pm 2.18$ & $11.16 \pm 0.96$ \\
\hline $10^{\text {th }}$ min & & & $23.52 \pm 0.10$ & $93.93 \pm 2.84$ & $11.06 \pm 0.62$ \\
\hline
\end{tabular}

AM: Aframomum melegueta; KS: Khaya senegalensis; XA: Xylopia aethiopica; Qur: Quercetin; Acg: Gallic acid. The values are expressed as a mean value \pm SD.

Photochemical screening and antioxidant activity: the phenols and flavonoids contained in plant extracts were determined respectively, using the Folin-Ciocalteu reagent reduction method and the aluminium chloride colorimetric method. The extracts of Khaya senegalensis and Aframomum meleguetahad the highest concentrations of polyphenols respectively of $329.21 \pm 19.99 \mathrm{mg}$ $E G A / 100 \mathrm{mg}$ and $174.45 \pm 14.62 \mathrm{mg} E G A / 100 \mathrm{mg}$ and flavonoids respectively of $1.39 \pm 0.07 \mathrm{mg} \mathrm{EQ} / 100 \mathrm{mg}$ and
$1.02 \pm 0.05 \mathrm{mg} E Q / 100 \mathrm{mg}$, in contrast to Xylopia aethiopica, which contained a low concentration (Table 2). Similarly, these plant extracts had the ability to complex DPPH- and ABTS+ free radicals. Khaya senegalensis had the highest antiradical activity $\left(\mathrm{IC}_{50}=\right.$ $6.37 \pm 0.09 \mu \mathrm{g} / \mathrm{mL}$ ) with the DPPH test while with the ABTS test, Aframomum meleguetaextracts had the highest inhibitory capacity $(32.79 \pm 3.79 \mathrm{mgEAA} / 100 \mathrm{mg}$ extract) followed by Khaya senegalensis extracts.

Table 2: Flavonoid and phenolic compounds and antioxidant activities

\begin{tabular}{|l|l|l|l|l|}
\hline \multicolumn{1}{|c|}{ Extracts } & $\begin{array}{c}\text { Total phenols }(\mathbf{m g} \text { EGA } \\
\text { /100mg) }\end{array}$ & $\begin{array}{c}\text { Total flavonoids } \mathbf{( m g} \\
\text { EQ/100mg) }\end{array}$ & \multicolumn{2}{c|}{ Antioxidant activities } \\
\cline { 3 - 5 } & & & $\begin{array}{c}\text { DPPH } \\
\left(\mathbf{I} \mathbf{C}_{50} \mathbf{\mu g} / \mathbf{m L}\right)\end{array}$ & $\begin{array}{c}\text { ABTS } \\
\text { (mgEAA/100mg) }\end{array}$ \\
\hline K. senegalensis & $329.21 \pm 19.99$ & $1.39 \pm 0.07$ & $6.37 \pm 0.09$ & $5.66 \pm 0.15$ \\
\hline A. melegueta & $174.45 \pm 14.62$ & $1.02 \pm 0.05$ & $22.26 \pm 2.15$ & $32.79 \pm 3.79$ \\
\hline $\boldsymbol{X}$. aethiopica & $15.27 \pm 1.09$ & $0.52 \pm 0.04$ & $2278.89 \pm 104.68$ & $1.89 \pm 0.19$ \\
\hline
\end{tabular}

Acute oral toxicity: Observations based on changes in skin, hair, salivation and behaviour, including various manifestations of tremor, convulsions, diarrhoea, sleep and coma. Apart from the diarrhoea observed in the lot that received Aframomum melegueta extracts, no abnor mal behaviour or deaths were observed in animals treated orally at any dose, which did not allow for the determination of the $L D_{50}$ (Table 1). The oral $L D_{50}$ for the hydro ethanol extract of Aframomum melegueta, Khaya senegalensis and Xylopia aethiopica is therefore greater than $5000 \mathrm{mg} / \mathrm{kg}$ bw.

Subchronic toxicity: During the treatment period, the rats showed no abnormal behaviour. However, in male rats, the lots that was treated with Khaya senegalensis extracts had lost weight from $14^{\text {th }}$ day onwards, unlike the one treated by Aframomum melegueta and Xylopia aethiopica. For female rats, the batches of Aframomum melegueta and the $300 \mathrm{mg} / \mathrm{Kg}$ b.w. dose of Khaya senegalensis had lost weight from to $7^{\text {th }}$ day and $14^{\text {th }}$ day respectively. Control lots in both sexes had gained weight (Figure 2). After sacrifice of the rats, no apparent difference was observed between the test and control lots. In addition, haematological analysis showed no significant changes in red blood cells count, haemoglobin levels, MCV, platelets, neutrophils and lymphocytes count in male rats, but the white blood cell, $\mathrm{MCH}, \mathrm{MCHC}$ and monocyte counts of the $300 \mathrm{mg} / \mathrm{kg}$ dose group of Khaya senegalensis increased (Table 3). The same trend was observed in female rats where white blood cell and platelet counts increased in the $300 \mathrm{mg} / \mathrm{kg}$ 
Ataba et al., J. Appl. Biosci. 2020 Toxicity, chemical composition, anti-inflammatory and antioxidant activities of plants used for the treatment of helminth infections in the Kara and central region of Togo.

b.w.dose of Aframomum melegueta and Khaya senegal ensis (Table 4). The same was for monocytes with the 100 and $300 \mathrm{mg} / \mathrm{Kg}$ bw doses of Aframomum melegueta. Neutrophil and basophilic polynuclear cells count in the $300 \mathrm{mg} / \mathrm{Kg}$ bw dose lots of Khaya senegalensis extract increased (Table 4). With respect to biochemical parameters, Alanine aminotransferase was significantly increased in the batch of male rats for the $300 \mathrm{mg} / \mathrm{Kg} \mathrm{bw}$ dose of Aframomum melegueta extract (Table 5). The same observation was made with creatinine and Alanine aminotransferase in male rats and then Aspartate aminotransferase and Alanine aminotransferase for the $300 \mathrm{mg} / \mathrm{Kg}$ b.w. dose of Khaya senegalensis (Tables 5 and 6). There were no significant variations between the organs of the male rats tested compared to the control except for the increase of the weight of the spleen and the kidneys for the $300 \mathrm{mg} / \mathrm{Kg} \mathrm{b.w}$. lot of Aframomum melegueta extract (Figure 3). On the other hand, the weight of livers, heart, lungs and kidneys of female rats, which had received the extracts of Aframomum melegueta and Khaya senegalensis, had significantly decreased (Figure 4). 

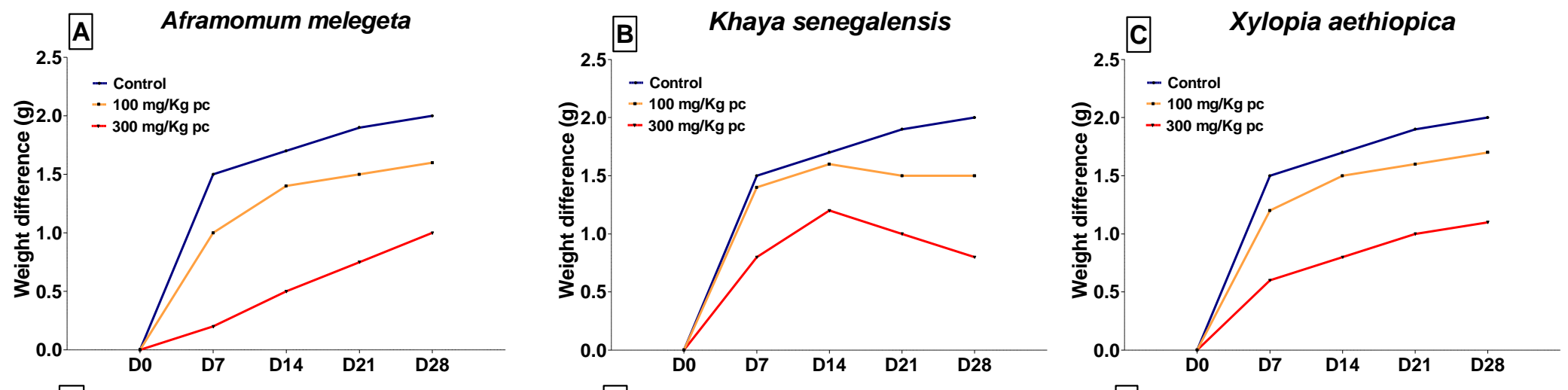

D.
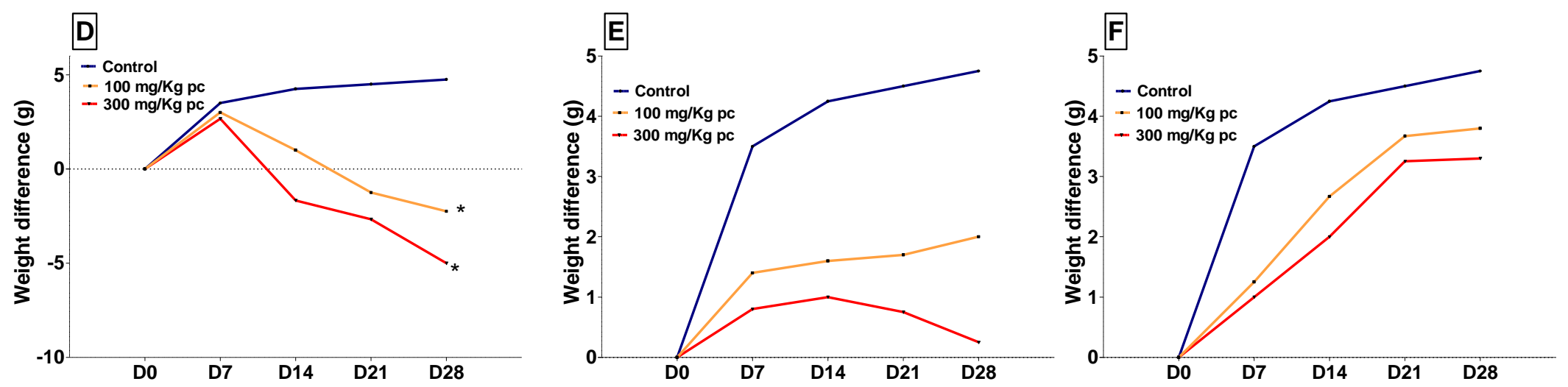

Figure 2: Variation of body weight of male and female rats at 100 and $300 \mathrm{mg} / \mathrm{kg}$ of Aframomum melegueta, Khaya senegalensis and Xylopia aethiopica. Male rats $(A, B$ and $C)$ and female rats $(D, E$ and F). D0, D7, D14 and D28 correspond to the 7-day interval of weight gains during the 28-day subchronic toxicity assessment. Asterisks show statistical differences (U test of Mann Whitney) between 100 and $300 \mathrm{mg} / \mathrm{Kg}$ bw doses vs Control $\left({ }^{*} p<0.05,{ }^{* *} p<0.01,{ }^{* * *} p<0.001\right)$.) 
Ataba et al., J. Appl. Biosci. 2020 Toxicity, chemical composition, anti-inflammatory and antioxidant activities of plants used for the treatment of helminth infections in the Kara and central region of Togo.

Table 3: Effects of hydroethanolic extracts of Aframomum melegueta (AM), Khaya senegalensis (KS) and Xylopia aethiopica (XA) on hematological parameters of male rats

\begin{tabular}{|c|c|c|c|c|c|c|c|c|c|}
\hline \multirow{2}{*}{ Parameters } & \multirow{2}{*}{ Control } & \multicolumn{4}{|c|}{$100 \mathrm{mg} / \mathrm{Kg}$} & \multicolumn{4}{|c|}{$300 \mathrm{mg} / \mathrm{Kg}$} \\
\hline & & AM & KS & XA & $p$ & AM & KS & XA & $p$ \\
\hline WBC $\left(10^{9} / \mathrm{L}\right)$ & $6.18 \pm 0.16$ & $7.74 \pm 3.36$ & $7.44 \pm 1.58$ & $7.91 \pm 2.87$ & & $6.27 \pm 1.74$ & $9.54 \pm 2.30^{*}$ & $6.40 \pm 1.66$ & 0.0286 \\
\hline $\operatorname{RBC}\left(10^{12} / \mathrm{L}\right)$ & $9.03 \pm 0.61$ & $9.23 \pm 0.49$ & $9.27 \pm 0.42$ & $8.83 \pm 0.41$ & & $9.235 \pm 0.18$ & $8.91 \pm 0.26$ & $9.02 \pm 0.18$ & \\
\hline $\mathrm{HB}(\mathrm{g} / \mathrm{dL})$ & $14.53 \pm 1.14$ & $14.78 \pm 0.75$ & $14.73 \pm 0.70$ & $14.10 \pm 0.74$ & & $14.68 \pm 0.41$ & $13.90 \pm 0.43$ & $14.15 \pm 0.17$ & \\
\hline НСТ (\%) & $50.73 \pm 4.40$ & $51.58 \pm 3.63$ & $52.45 \pm 2.46$ & $48.60 \pm 4.93$ & & $52.78 \pm 0.45$ & $49.98 \pm 1.13$ & $49.93 \pm 0.45$ & \\
\hline MCV (fL) & $56.08 \pm 1.08$ & $55.85 \pm 2.10$ & $56.55 \pm 1.17$ & $54.90 \pm 3.14$ & & $57.08 \pm 0.89$ & $56.08 \pm 0.42$ & $55.43 \pm 1.32$ & \\
\hline $\mathrm{MCH}(\mathrm{pg})$ & $16.08 \pm 0.21$ & 16.00 & $15.85 \pm 0.19$ & $15.95 \pm 0.25$ & & $15.88 \pm 0.13$ & $15.60 \pm 0.08$ & $15.70 \pm 0.42$ & \\
\hline $\mathrm{MCHC}(\mathrm{g} / \mathrm{dL})$ & $28.63 \pm 0.24$ & $28.70 \pm 1.09$ & $28.08 \pm 0.42$ & $29.15 \pm 1.62$ & & $27.80 \pm 0.67$ & $27.80 \pm 0.22^{*}$ & $28.33 \pm 0.10$ & 0.0284 \\
\hline PLT (109/L) & $771.0 \pm 98.86$ & $800.8 \pm 140.6$ & $796.3 \pm 127.6$ & $890.5 \pm 170.2$ & & $789.3 \pm 136.2$ & $804.0 \pm 79.05$ & $745.8 \pm 56.57$ & \\
\hline NEU $(109 / \mathrm{L})$ & $1386 \pm 458.2$ & $1568 \pm 691.3$ & $1603 \pm 589.7$ & $2753 \pm 2845$ & & $1274 \pm 40.45$ & $3314 \pm 1442$ & $1888 \pm 1013$ & \\
\hline LYM (109/L) & $5463 \pm 982.5$ & $5279 \pm 1706$ & $5855 \pm 722.8$ & $3681 \pm 1805$ & & $4872 \pm 1503$ & $4732 \pm 495.6$ & $5173 \pm 747.7$ & \\
\hline MO (109/L) & $483.0 \pm 66.14$ & $2397 \pm 2864^{*}$ & $1033 \pm 787.3$ & $2988 \pm 803^{*}$ & $\begin{array}{r}0.0294 ; \\
0.0294\end{array}$ & $3099 \pm 2584^{*}$ & $1254 \pm 625.7^{*}$ & $633.0 \pm 527.4$ & 0.0294 \\
\hline EO (109/L) & $1485 \pm 1371$ & $382.5 \pm 257.3$ & $1037 \pm 581.0$ & $361.7 \pm 448.0$ & & $350.0 \pm 247.5$ & $499.7 \pm 11.26$ & $123.5 \pm 247.0$ & \\
\hline BAS $\left(10^{9} / \mathrm{L}\right)$ & $6342 \pm 584.3$ & $2928 \pm 1670^{*}$ & $2845 \pm 1432^{*}$ & $3477 \pm 2487^{*}$ & $\begin{array}{c}0.0286 ; \\
0.0286 ; \\
0.0286\end{array}$ & $2298 \pm 1257^{*}$ & $2802 \pm 454.4^{*}$ & $5131 \pm 735.5$ & $\begin{array}{c}0.0286 \\
0.0286\end{array}$ \\
\hline
\end{tabular}

Values represent the mean \pm SD ( $n=4 /$ group) of haematological parameters; ${ }^{*} p<0.05$ vs. Control. WBC: White blood cells; RBC: Red blood cell; HB: Haemoglobin; HCT: Haematocrit; MCV: mean corpuscular volume; MCH: mean corpuscular haemoglobin; MCHC: mean corpuscular haemoglobin concentration; PLT: Platelets; NEU: Neutrophils; LYM: Lymphocytes; MO: Monocytes; EO: Eosinophils; BAS: Basophils. 
Ataba et al., J. Appl. Biosci. 2020 Toxicity, chemical composition, anti-inflammatory and antioxidant activities of plants used for the treatment of helminth infections in the Kara and central region of Togo.

Table 4: Effects of hydroethanolic extracts of Aframomum melegueta (AM), Khaya senegalensis (KS) and Xylopia aethiopica (XA) on haematological parameters of female rats

\begin{tabular}{|c|c|c|c|c|c|c|c|c|c|}
\hline \multirow{2}{*}{ Parameters } & \multirow{2}{*}{ Control } & \multicolumn{4}{|c|}{$100 \mathrm{mg} / \mathrm{Kg}$} & \multicolumn{4}{|c|}{$300 \mathrm{mg} / \mathrm{Kg}$} \\
\hline & & AM & KS & XA & $p$ & AM & KS & XA & $p$ \\
\hline WBC $(109 / L)$ & $4.8 \pm 0.72$ & $6.31 \pm 0.67$ & $6.32 \pm 0.421$ & $8.54 \pm 2.15$ & & $8.93 \pm 0.19^{*}$ & $10.78 \pm 1.48^{*}$ & $7.01 \pm 1.14$ & \\
\hline $\operatorname{RBC}\left(10^{12 / L}\right)$ & $6.5 \pm 2.49$ & $7.92 \pm 0.55$ & $7.43 \pm 1.05$ & $9.17 \pm 0.94$ & & $8.97 \pm 0.25$ & $8.38 \pm 0.38$ & $8.64 \pm 0.12$ & \\
\hline $\mathrm{HB}(\mathrm{g} / \mathrm{dL})$ & $12.13 \pm 1.79$ & $13.03 \pm 1.07$ & $12.90 \pm 1.23$ & $15.00 \pm 1.68$ & & $14.73 \pm 0.53$ & $13.83 \pm 0.53$ & $14.08 \pm 0.40$ & \\
\hline HCT $(\%)$ & $36.40 \pm 12.40$ & $46.90 \pm 2.92$ & $46.85 \pm 4.51$ & $54.98 \pm 4.14$ & & $52.38 \pm 1.19$ & $48.90 \pm 1.20$ & $50.98 \pm 1.12$ & \\
\hline MCV (fL) & $57.40 \pm 3.82$ & $59.20 \pm 1.06$ & $63.43 \pm 3.61$ & $60.08 \pm 1.72$ & & $58.50 \pm 0.70$ & $58.48 \pm 2.05$ & $58.93 \pm 0.61$ & \\
\hline $\mathrm{MCH}(\mathrm{pg})$ & $21.53 \pm 7.967$ & $16.43 \pm 0.38$ & $17.45 \pm 0.89$ & $16.35 \pm 0.33$ & & $16.43 \pm 0.19$ & $16.53 \pm 0.13$ & $16.28 \pm 0.26$ & \\
\hline MCHC (g/dL) & $36.83 \pm 10.94$ & $27.78 \pm 0.53^{*}$ & $27.55 \pm 0.26^{*}$ & $29.25 \pm 1.15$ & $\begin{array}{c}0.0286 \\
0.0286\end{array}$ & $28.10 \pm 0.43^{*}$ & $28.28 \pm 0.82$ & $27.60 \pm 0.24^{*}$ & $\begin{array}{c}0.0286 ; \\
0.0294\end{array}$ \\
\hline PLT (109/L) & $1192 \pm 166.5$ & $1237 \pm 146.7$ & $945.5 \pm 162.4$ & $849.5 \pm 92.19$ & & $764.3 \pm 21.36^{*}$ & $840.7 \pm 53.82^{*}$ & $1145 \pm 105.1$ & $\begin{array}{c}0.0286 \\
0.0286\end{array}$ \\
\hline NEU (109/L) & $1867 \pm 579.7$ & $2591 \pm 1134$ & $2528 \pm 531.3$ & $4055 \pm 2864$ & & $2266 \pm 522.2$ & $5273 \pm 2296^{*}$ & $2950 \pm 756.7$ & 0.0286 \\
\hline LYM $(109 / L)$ & $3477 \pm 1631$ & $3844 \pm 928.2$ & $2489 \pm 357.3$ & $2995 \pm 1851$ & & $4670 \pm 487.3$ & $3044 \pm 166.4$ & $3367 \pm 1091$ & \\
\hline MO (109/L) & $453.3 \pm 267.5$ & $1241 \pm 435.7^{*}$ & $912.5 \pm 270.6$ & $2364 \pm 3261$ & 0.0286 & $2457 \pm 955.2^{*}$ & $1262 \pm 592.2$ & $1699 \pm 948.2^{*}$ & 0.0286 \\
\hline EO (109/L) & $332.0 \pm 469.5$ & $152.7 \pm 215.9$ & $538.0 \pm 644.0$ & $131.5 \pm 263.0$ & & $170.7 \pm 241.4$ & $485.7 \pm 388.9$ & $501.3 \pm 403.5$ & \\
\hline BAS $(109 / \mathrm{L})$ & $3178 \pm 1271$ & $2159 \pm 980.5$ & $6321 \pm 3817$ & $2713 \pm 1829$ & & $1956 \pm 568.6$ & $8384 \pm 1594^{*}$ & $1964 \pm 277.6$ & 0.0286 \\
\hline
\end{tabular}

Values represent the mean \pm SD ( $n=4 /$ group); ${ }^{*} p<0.05$ vs. Control. WBC: White blood cells; RBC: Red blood cell; HB: Haemoglobin; HCT: Haematocrit; MCV: mean corpuscular volume; MCH: mean corpuscular haemoglobin; MCHC: mean corpuscular haemoglobin concentration; PLT: Platelets; NEU: Neutrophils; LYM: Lymphocytes; MO: Monocytes; EO: Eosinophils; BAS: Basophils. 
Ataba et al., J. Appl. Biosci. 2020 Toxicity, chemical composition, anti-inflammatory and antioxidant activities of plants used for the treatment of helminth infections in the Kara and central region of Togo.

Table 5: Effects of hydroethanolic extracts of Aframomum melegueta (AM). Khaya senegalensis (KS) and Xylopia aethiopica (XA) on biochemical parameters of male rats

\begin{tabular}{|c|c|c|c|c|c|c|c|c|c|}
\hline \multirow[t]{2}{*}{ Parameters } & \multirow[t]{2}{*}{ Control } & \multicolumn{3}{|c|}{$100 \mathrm{mg} / \mathrm{Kg}$} & \multirow[b]{2}{*}{$p$} & \multirow[b]{2}{*}{ AM } & \multirow{2}{*}{$\frac{300 \mathrm{mg} / \mathrm{Kg}}{\mathrm{KS}}$} & \multirow[b]{2}{*}{ XA } & \multirow[b]{2}{*}{$p$} \\
\hline & & AM & KS & XA & & & & & \\
\hline Glucose (g/L) & $0.97 \pm 0.14$ & $1.1 \pm 0.18$ & $1.15 \pm 0.13$ & $1.19 \pm 0.17$ & & $1.05 \pm 0.26$ & $1.05 \pm 0.13$ & $1.01 \pm 0.37$ & \\
\hline Urea (g/L) & $0.29 \pm 0.07$ & $0.31 \pm 0.06$ & $0.31 \pm 0.15$ & $0.29 \pm 0.04$ & & $0.31 \pm 0.08$ & $0.33 \pm 0.09$ & $0.32 \pm 0.09$ & \\
\hline Creatinine $(\mathrm{g} / \mathrm{dL})$ & $0.90 \pm 0.07$ & $0.89 \pm 0.03$ & $0.84 \pm 0.04$ & $0.74 \pm 0.09$ & & $0.84 \pm 0.03$ & $0.77 \pm 0.05^{*}$ & $0.82 \pm 0.08$ & 0.0294 \\
\hline AST (U/L) & $110 \pm 11.53$ & $119.8 \pm 10.24$ & $123.8 \pm 11.09$ & $121.8 \pm 13.20$ & & $116.8 \pm 9.74$ & $131.5 \pm 9.47$ & $127.5 \pm 15.02$ & \\
\hline ALT (U/L) & $72.25 \pm 4.57$ & $88.0 \pm 4.97$ & $75.5 \pm 6.24$ & $86.8 \pm 33.98$ & & $96.00 \pm 4.32^{*}$ & $92.00 \pm 8.2^{*}$ & $87.75 \pm 7.41$ & $\begin{array}{c}0.0286 ; \\
0.0286\end{array}$ \\
\hline ALP (U/L) & $184.3 \pm 20.87$ & $146.3 \pm 7.85$ & $133.3 \pm 19.60$ & $201.3 \pm 15.28$ & & $176.5 \pm 11.82$ & $171.8 \pm 8.261$ & $157.8 \pm 10.72$ & \\
\hline
\end{tabular}

The values represent the mean \pm SD ( $n=4 /$ sex / group) ${ }^{*} p<0.05$ vs. Control. AST: Aspartate aminotransferase; ALT: Alanine aminotransferase; ALP: Alkaline phosphatase.

Table 6: Effects of hydroethanolic extracts of Aframomum melegueta (AM), Khaya senegalensis (KS) and Xylopia aethiopica (XA) on biochemical parameters of female rats

\begin{tabular}{|c|c|c|c|c|c|c|c|c|c|}
\hline \multirow{2}{*}{ Parameters } & \multirow{2}{*}{ Control } & \multicolumn{4}{|c|}{$100 \mathrm{mg} / \mathrm{Kg}$} & \multicolumn{4}{|c|}{$300 \mathrm{mg} / \mathrm{Kg}$} \\
\hline & & AM & KS & $X A$ & $p$ & AM & KS & $X A$ & $p$ \\
\hline Glucose (g/L) & $0.75 \pm 0.12$ & $1.02 \pm 0.21$ & $1.09 \pm 0.18$ & $0.97 \pm 0.24$ & & $1.06 \pm 0.14$ & $1.06 \pm 0.19$ & $1.07 \pm 0.30$ & \\
\hline Urea (g/L) & $0.33 \pm 0.08$ & $0.44 \pm 0.17$ & $0.38 \pm 0.17$ & $0.34 \pm 0.08$ & & $0.46 \pm 0.24$ & $0.53 \pm 0.09$ & $0.46 \pm 0.23$ & \\
\hline Creatinine $(\mathrm{g} / \mathrm{dL})$ & $0.84 \pm 0.06$ & $0.83 \pm 0.05$ & $0.78 \pm 0.04$ & $19.31 \pm 37.13$ & & $0.75 \pm 0.03$ & $0.82 \pm 0.01$ & $0.73 \pm 0.08$ & \\
\hline AST (U/L) & $123.0 \pm 6.05$ & $126.8 \pm 3.86$ & $139.5 \pm 7.50$ & $126.8 \pm 12.04$ & & $135.3 \pm 16.03$ & $147.0 \pm 7.35^{*}$ & $123.3 \pm 5.74$ & 0.0286 \\
\hline ALT (U/L) & $45.50 \pm 5.80$ & $55.75 \pm 9.94$ & $44.25 \pm 5.32$ & $70.50 \pm 14.20$ & & $59 \pm 5.48$ & $68.25 \pm 13.94^{*}$ & $49.50 \pm 10.02$ & 0.0294 \\
\hline ALP (U/L) & $182.3 \pm 7.37$ & $191.0 \pm 23.42$ & $181.3 \pm 10.81$ & $201.0 \pm 12.36$ & & $210.0 \pm 33.85$ & $193.8 \pm 18.26$ & $206.8 \pm 12.53$ & \\
\hline
\end{tabular}

The values represent the mean \pm SD $\left(n=4 /\right.$ sex / group) ${ }^{*} p<0.05$ vs. Control. AST: Aspartate aminotransferase; ALT: Alanine aminotransferase; ALP: Alkaline phosphatase. 

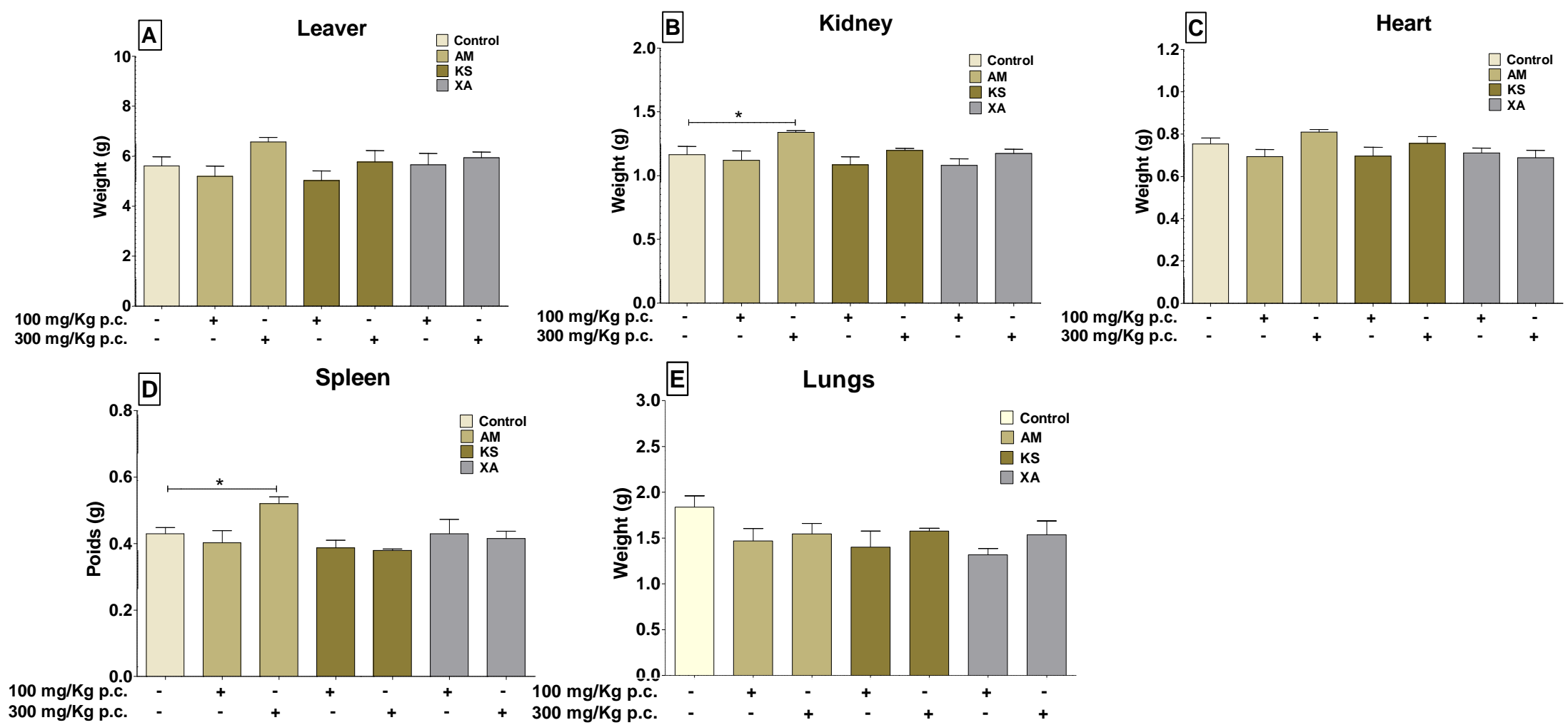

Figure 3: Effects of hydroethanolic extracts of Aframomum melegueta ( $A M)$, Khaya senegalensis $(K S)$ and Xylopia aethiopica $(X A)$ on organ weights in male rats. Asterisks show statistical differences (U test of Mann Whitney) between the groups indicated by the brackets $\left({ }^{*} p<0.05,{ }^{* *} p<0.01,{ }^{* * *} p<0.001\right)$. 

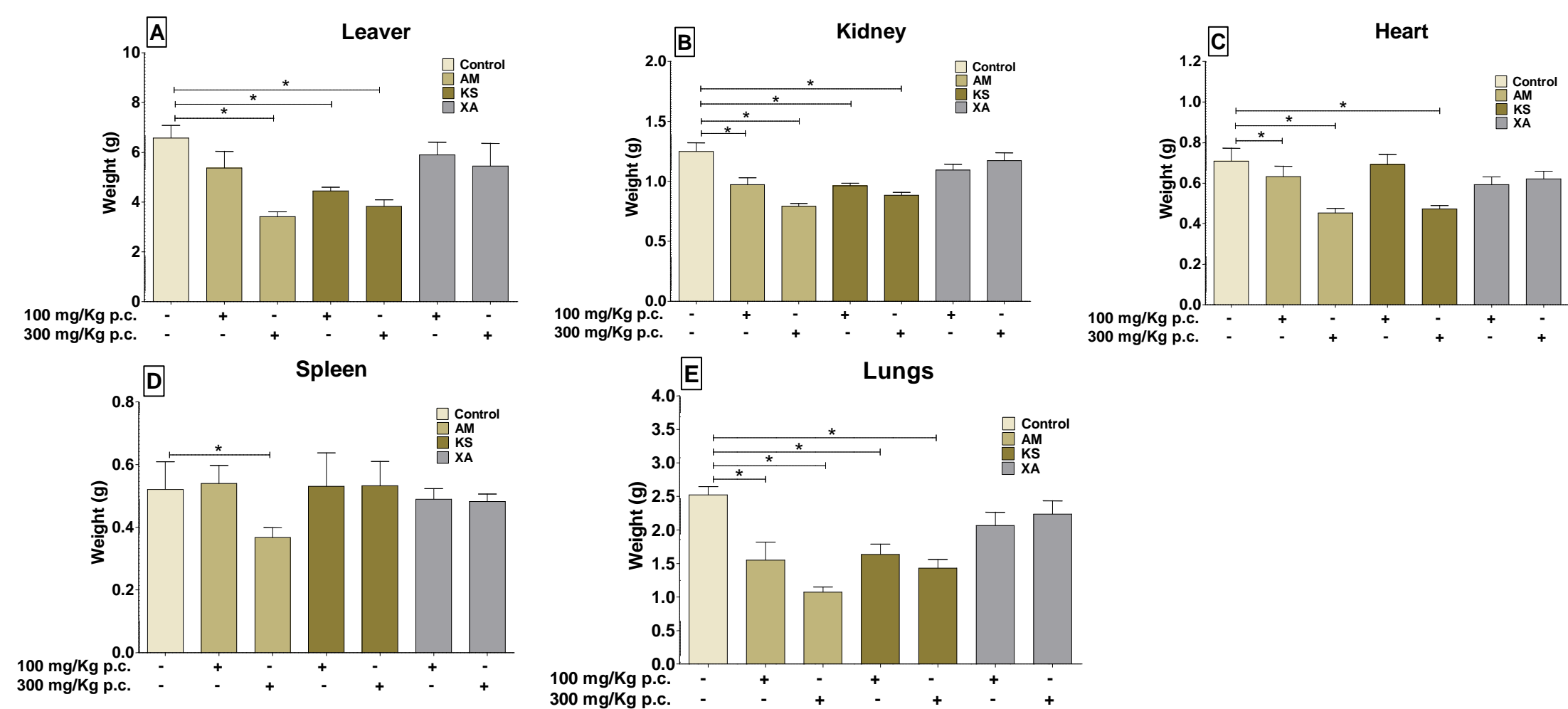

Figure 4: Effects of hydroethanolic extracts of Aframomum melegueta (AM), Khaya senegalensis (KS) and Xylopia aethiopica (XA) on organ weights in female rats. Asterisks show statistical differences (U test of Mann Whitney) between the groups indicated by the brackets $\left({ }^{*} p<0.05,{ }^{* *} p<0.01,{ }^{* * *} p<0.001\right)$. 


\section{DISCUSSION}

Medicinal plants are now increasingly used in the African pharmacopoeia (Karou et al., 2011;Tchacondo, 2011WHO, 2012). These plants are a source of multitudes of molecules potentially effective against diseases (Rout et al., 2009;Veeresham, 2012Shakya, 2016). Following our recent studies, the trunk bark of Khaya senegalensis, the grains of Aframomum melegueta and the fruits of Xylopia aethiopica used by THs in the Central and Kara regions of Togo, for the treatment of helminthiases showed a real antihelmintic activity (Ataba et al., 2020). The objective of this study was to investigate the anti-inflammatory, antioxidant activity and toxicity of these main plants used for the treatment of helminthiases. The results obtained in this study confirm the anti-inflammatory potential of hydroethanol extracts of Aframomum melegueta, Khaya senegalensis and Xylopia aethiopica through the inhibition of type I-B lipoxygenase to varying. Lipoxygenases are an extensively studied class of enzymes recognized classically as drug targets for the treatment of inflammation. (Wisastra and Dekker, 2014). Then, a variety of compounds have been introduced to modulate lipoxygenase enzyme activity and ultimately to provide new drugs for inflammation (Wisastra and Dekker, 2014). Given that, helminth infections induced inflammatory conditions such as skin disorder, elephantiasis (Hoerauf et al.,2003; Hoerauf 2005, Katawa et al., 2015), the use of these plants by THs to treat helminth infection is for good interest. This result is consistent with that of Jiang et al. (2013) who found a $62 \%$ inhibition of foot oedema in animals with a petroleum ether extract at 0.5 and $1 \mathrm{~g} / \mathrm{kg}$. Ademola et al., suggested the use of Khaya senegalensis extract in anthelmintic therapy in veterinary practice (Ademola et al., 2004). The anti-trypanosomal activity of Khaya senegalensis has also been studied by some authors (Ibrahim et al., 2013). While Xylopia aethiopica inhibit lipoxygenase at $65.22 \pm 1.63 \%$, the extract of this plant is the poorest in phenolic and flavonoid compounds. Xylopia aethiopica was mainly used for healing Lymphatic Filariasis, Schistosomiasis (Oloyede and Aduramigba-Modupe, 2011). Xylopia aethiopica is commonly used in Nigeria by THs to treat parasitic gastrointestinal helminths (Suleiman et al., 2005). In addition, the ethanolic extract of Aframomum melegueta has anti-inflammatory properties by inhibiting the activity of cyclooxygenase-2 (COX-2) (llic et al., 2014). Aframomum melegueta seeds are also used in Africa to control diarrhoea and gastroenteritis (Jiofack et al., 2008). The pathogenicity of helminths infections such as skin disorder, elephantiasis, is the result of the inflammatory reactions to these parasites (Maizels and Lawrence, 1991, Taylor, 2003, Van Riet et al., 2007). This would justify their traditional uses in the treatment of helminths infections. Furthermore, this study found that these plants had anthelmintic effect with lethal doses values of $233 \mu \mathrm{g} / \mathrm{mL}, 265 \mu \mathrm{g} / \mathrm{mL}$ and $550 \mu \mathrm{g} / \mathrm{mL}$, respectively for Xylopia aethiopica, Aframomum melegueta and Khaya senegalensis (Ataba et al., 2020). Phytochemical screening of the plant revealed that Aframomum melegueta, Xylopia aethiopica and Khaya senegalensis contain phenolic and flavonoid compounds. The results of this study show that among the extracts studied, it is the trunk bark of Khaya senegalensis that contains the most, i.e. $329.21 \pm 19.99$ $\mathrm{mg}$ of gallic acid equivalent per $100 \mathrm{mg}$ of sample. This result is 697.6 times higher than that of Karou et al., (2005) who found a value of $47.19 \pm 0.13 \mu \mathrm{g}$ gallic acid per gram of sample taken in Ouagadougou (Karou et al., 2005). This large difference could be due to the different climatic and soil conditions on the one hand and on the other hand to the degree of maturity of the plants at the time of sample collection. Phenolic compounds not only play a physiological role, a means of plant defence (ElHalawany et al., 2014) and a tool for attracting pollinating agents, but are also powerful antioxidants. Indeed, previous studies have shown that phenolic compounds have the capacity to adsorb free radicals (Koba et al., 2008; Idoh et al., 2013; Toudji et al., 2018). It is true that many synthetic molecules are currently prescribed to alleviate these physiological disorders; however, not only are plant-based antioxidants more protective than synthetic antioxidants (Akter et al., 2014), they are also accessible to all budgets and are renewable. DPPH and ABTS tests were used to show antioxidant activities of plants extracts. The present study, found the capacity of phenols to adsorb free radicals. Moreover, the difference in phenol results observed with those of Karou et al., (2005) is also reflected in the ability of both samples to complex the ABTS+ radical (Karou et al., 2005). The DPPH test is used to measure the anti-radical power of pure molecules or plant extracts (Da Porto et al., 2000; Tirzitis and Bartoz, 2010). It measures the ability of an antioxidant to reduce the chemical radical DPPH- by transferring a hydrogen atom. Statistical analysis applied to the results of the antioxidant activities of these three types of extracts, measured with ABTS+ staining, shows that these results are significantly different at $(P<0.05$, $n=3$ ). This could mean that each extract of this plant has 

used for the treatment of helminth infections in the Kara and central region of Togo.

a different molecular composition and therefore deserves to be studied. The results of this present work prove that these plant extracts are good natural antioxidants and that their use in phytotherapy can help the human body to deal with an imbalance between the production and regulation of free radicals. The dosage and the lack of information on the toxicity of medicinal plants are the main reasons and the brake on the development of phytotherapy (Sharma et al., 2010). Here, the acute toxicity study revealed no abnormal behaviour or deaths were observed in animals treated orally with the dose of $5000 \mathrm{mg} / \mathrm{Kg}$ of bw except for the diarrhoea observed on the lot that received the extracts of Aframomum melegueta. The oral $\mathrm{LD}_{50}$ of the hydroethanolic extract of Aframomum melegueta, Khaya senegalensis and Xylopia aethiopica is thus higher than $5000 \mathrm{mg} / \mathrm{Kg}$ bw. However, female rats dosed with 300 $\mathrm{mg} / \mathrm{Kg}$ of Aframomum melegueta and Khaya senegalensis extracts lost weight from $7^{\text {th }}$ day and $14^{\text {th }}$ day respectively while control lots in both sexes had a weight gain. After sacrifice of the rats, no apparent difference was observed between the test and control lots. This was confirmed by haematological analysis, which showed no significant changes in red blood cells, haemoglobin level, platelets, neutrophils and lymphocytes in male rats, but white blood cell count, $\mathrm{MCH}, \mathrm{MCHC}$ and monocytes in the $300 \mathrm{mg} / \mathrm{Kg}$ dose lot of Khaya senegalensis were increased. Similarly, the same trend was observed in female rats where white blood cell and platelet counts were increased in the 300 $\mathrm{mg} / \mathrm{Kg}$ dose of Aframomum melegueta and Khaya senegalensis. Lots of the $300 \mathrm{mg} / \mathrm{Kg}$ dose of Khaya senegalensis extracts showed increases in neutrophils and basophils. This would be the dose effect as similar studies have shown toxicity of Aframomum melegueta and Khaya senegalensis at high doses (llic et al., 2010; Onu et al., 2013). Alanine aminotransferase is a cytosolic enzyme secreted by liver cells and released into the bloodstream in the event of hepatic cell necrosis (Kaneko, 1995, Dufour et al., 2000). It is an important indicator of hepatotoxicity (Pratt and Kaplan, 2000). Aspartate aminotransferase is also an indicator of hepatocyte destruction, Although in addition to the liver, it is present in the heart, skeletal muscles, lungs and kidneys (Dufour et al., 2000). Levels of Alanine

\section{CONCLUSION AND APPLICATION OF RESULTS}

Togolese plant organ extracts have various properties that can be useful in healing diseases. In our context, extracts of Khaya senegalensis and Xylopia aethiopica have an interesting capacity to inhibit lipoxygenase. In aminotransferase and Aspartate aminotransferase rise rapidly when the liver is damaged for a variety of reasons including hepatic cell necrosis, hepatitis, cirrhosis, and hepatotoxicity of certain drugs (Dufour et al., 2000; Pratt and Kaplan, 2000). In our study, the concentration of Alanine aminotransferase in the male batch that took the $300 \mathrm{mg} / \mathrm{Kg}$ dose of Aframomum melegueta extract was significantly increased. The same observation is made with creatinine and Alanine aminotransferase in male rats and then Aspartate aminotransferase and Alanine aminotransferase for the $300 \mathrm{mg} / \mathrm{Kg}$ dose of Khaya senegalensis. The same result has been reported by other authors with increases in Alanine aminotransferase, Aspartate aminotransferase and alkaline phosphatase in rats with higher doses of Khaya senegalensis (Yakubu et al., 2005; Onu et al., 2013). The biochemical and haematological parameters measured are indicative of the physiological state of vital organs in rats. Therefore, the variations of these parameters would explain those observed in the organs. In male rats, only an increase of spleen and kidneys weights was observed in the $300 \mathrm{mg} / \mathrm{Kg}$ lot of Aframomum melegueta extract compared to the control batch. The organs of female rats showed some variation mainly for the extracts of Aframomum melegueta and Khaya senegalensis. These were livers, heart, lungs and kidneys for the doses of 100 and $300 \mathrm{mg} / \mathrm{Kg}$, which experienced a significant decrease in weight. On the other hand, Aframomum melegueta was found to have a hepato-protective effect on rats (Idoh et al., 2013). In addition to its hepatoprotective potential, Aframomum melegueta is believed to have anti-apoptotic activity (Gbekley et al., 2017). No signs of toxicity were observed for the extract of Xylopia aethiopica but studies have demonstrated its toxicity at higher doses (Obodo et al., 2013; Obhakhan et al., 2014; Chris-Ozoko et al., 2015). There was no mortality during the experiment, so variations in biological parameters do not completely affect the safety of these extracts at low doses. Similarly, these data are broadly consistent with previous results of our team who found that Aframomum melegueta and Xylopia aethiopica were not cytotoxic at $200 \mu \mathrm{g} / \mathrm{mL}$ but Khaya senegalensis showed moderate toxicity with peripheral blood mononuclear cell mortality greater than $20 \%$ at the same concentration (Ataba et al., 2020).

addition, extracts of Khaya senegalensis and Aframomum melegueta have the highest concentrations of polyphenols, flavonoids and have the capacity to complex DPPH- and ABTS+ free radicals. Our data 
suggest that acute and subchronic toxicity oral administration of the hydroalcoholic extract of these extracts did not produce significant toxic effects in male and female Wistar rats. Thus, this could provide assurance for the medical use of these plants in traditional medicine of Togo. Through these pharmacological actions of these plant extracts could be exploited in the development of treatments for inflammatory disorders caused by helminths. For this purpose, additional studies would be necessary to determine the molecules involved in the pharmacological properties of these plant organ extracts as well as their modes of action.

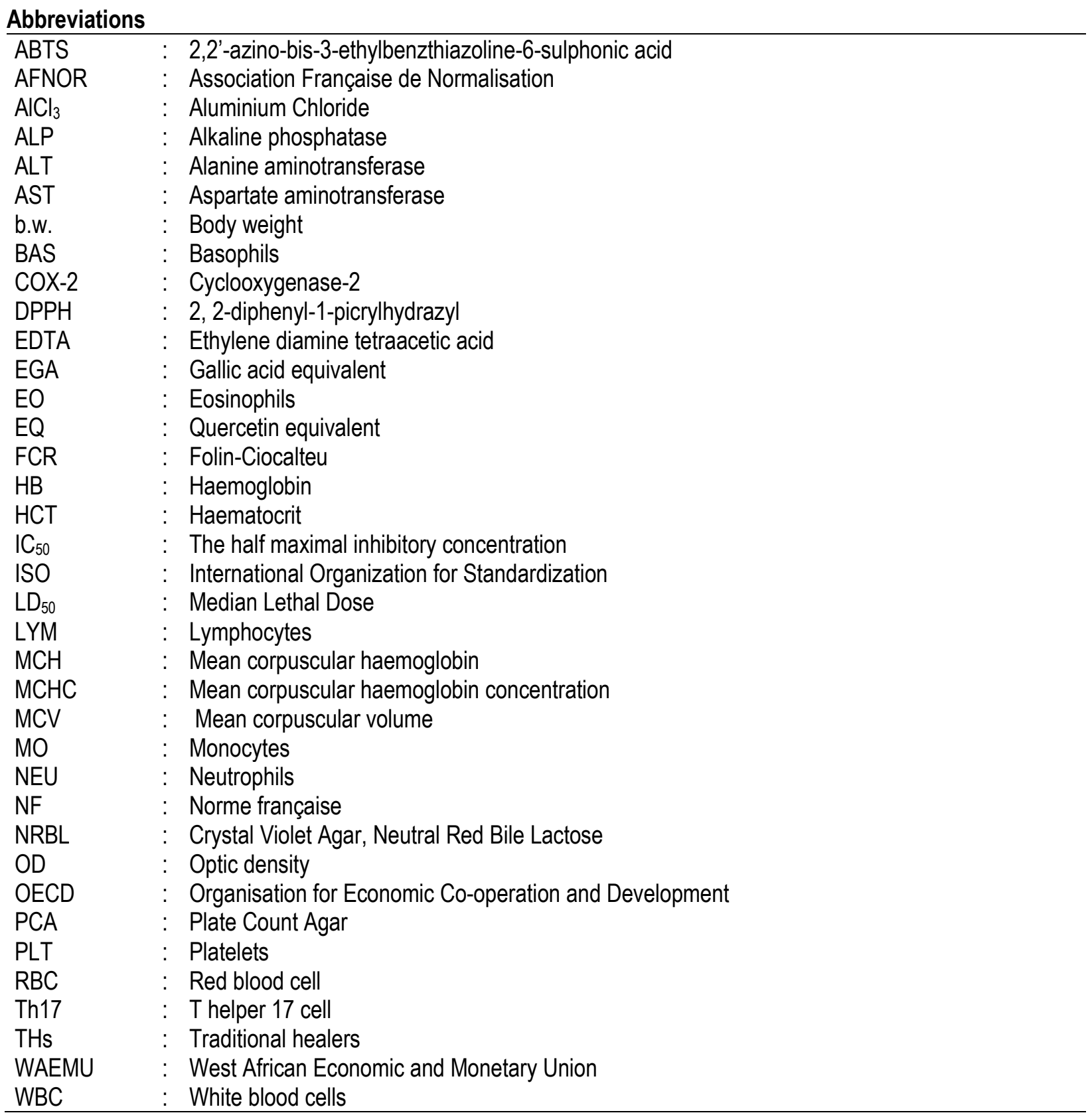

Data Availability: The datasets during and/or analysed during the current study available from the corresponding author on reasonable request.

Funding: This study was funded by a grant from the German Research Council (DFG: LA2746/1-1). 
Ataba et al., J. Appl. Biosci. 2020 Toxicity, chemical composition, anti-inflammatory and antioxidant activities of plants used for the treatment of helminth infections in the Kara and central region of Togo.

\section{ACKNOWLEDGMENTS}

We thank all of the traditional healers from the NGO CERMETRA in participating in the study and sharing their knowledge.

Conflicts of Interest: The authors declare that they have no competing interests

\section{REFERENCES}

Ademola, I. O., Fagbemi, B. O. \& Idowu, S. O. 2004. Evaluation of the anthelmintic activity of Khaya senegalensis extract against gastrointestinal nematodes of sheep: in vitro and in vivo studies. Veterinary Parasitology, 122, 151-164.

AFNOR 2009. (Association Française de Normalisation) Normes Agroalimentaires.

Akter, K., Karmakar, P., Das, A., Anonna, S., Shoma, S. \& Sattar, M. 2014. Evaluation of antibacterial and anthelmintic activities with total phenolic contents of Piper betel leaves. Avicenna Journal of Phytomedicine, 4, 320-9.

Arvouet-Grand, A., Vennat, B., Pourrat, A. \& Legret, P. 1994. [Standardization of propolis extract and identification of principal constituents]. Journal de pharmacie de Belgique, 49, 462-468.

Ataba, E., Katawa, G., Ritter, M., Ameyapoh, A., Anani, K., Amessoudji, O. M., Tchadié, P., Batawila, K., Tchacondo, T., Ameyapoh, Y., Hoerauf, A., Layland, E. \& Karou, S. 2020. Plants species used for the treatment of Tropical Neglected Diseases in the Central and Kara regions of Togo: ethnopharmacological study, antihelminthic effects and cytotoxicity. BMC Biotechnol.

Bürger, C., Fisher, D., Cordenunzzi, D., Batschauer, A., Filho, V. \& Soares, A. 2005. Acute and subacute toxicity of hydroalcoholic extract from Wedelia paludosa (Acmelia brasiliensis) (Asteraceae) in mice. J. Pharm. Pharmaceut. Sci., 8, 370-373.

Chris-Ozoko, L., Ekundina, V. \& Winiki, C. 2015. Histomorphological Effects of Xylopia aethiopica on the Liver and Kidney of Albino Wistar Rats. Sch. Acad. J. Biosci, 3, 1-5.

Da Porto, C., Calligaris, S., Celotti, E. \& Nicoli, M. 2000. Antiradical Properties of Commercial Cognacs Assessed by the DPPH test. J. Agric. Food Chem., 48.

Dufour, D. R., Lott, J. A., Nolte, F. S., Gretch, D. R., Koff, R. S. \& Seeff, L. B. 2000. Diagnosis and Monitoring of Hepatic Injury. I. Performance Characteristics of Laboratory Tests. Clin. Chem, 46, 2027-2049.
El-Halawany, A. M., El Dine, R. S., El Sayed, N. S. \& Hattori, M. 2014. Protective Effect ofAframomum meleguetaphenolics Against CCl4-Induced RatHepatocytes Damage; Role of Apoptosis and Pro-inflammatory Cytokines inhibition. Sci.Rep, 4.

Gbekley, H. E., Katawa, G., Karou, S. D., Anani, S., Tchadjobo, T., Ameyapoh, Y. \& Simpore, J. 2017. Ethnobotanical study of plants used to treat asthma in the maritime region in Togo. Afr. J. Tradit. Complement. Altern. Med., 14, 196212.

Hoerauf, A. 2008. Filariasis: new drugs and new opportunities for lymphatic filariasis and onchocerciasis. Curr Opin Infect Dis, 21, 67381

Hoerauf, A., Büttner, D. W., Adjei, O. \& Pearlman, E. 2003. Onchocerciasis. Bmj, 326, 207-10.

Hoerauf, A., Pfarr, K., Mand, S., Debrah, A. Y. \& Specht, S. 2011. Filariasis in Africa-treatment challenges and prospects. Clin. Microbiol. Infect, 17, 977-985.

Hoerauf, A. E. A. 2005. Immunomodulation by filarial nematodes. Parasite Immunol, 27, 417-29.

Ibrahim, M., Musa, A., Aliyu, A., Mayaki, H., Gideon, A. \& Islam, M. 2013. Phenolics-rich fraction of Khaya senegalensis stem bark: antitrypanosomal activity and amelioration of some parasite-induced pathological changes. Pharm Biol, 51, 906-13.

Idoh, K., Karou, D., Agbonon, A., Adjrah, Y. \& Gbeassor, M. 2013. Effect of Aframomum melegueta on carbon tetrachloride induced liver injury. J. Appl. Pharm, 3, 098-102.

Ilic, N., Schmidt, B. M., Poulev, A. \& Raskin, I. 2010. Toxicological evaluation of Grains of Paradise (Aframomum melegueta) [Roscoe] K. Schum. J. Ethnopharmacol, 127, 352-356.

Ilic, N. M., Dey, M., Poulev, A., Logendra, S., Kuhn, P. \& Raskin, I. 2014. Anti-inflammatory Activity of Grains of Paradise (Aframomum melegueta Schum) Extract. J. Agric. Food Chem, 62, 10452-10457. 
Jiang, B., Chi, C., Y-W., F., Zhang, Q.-Z. \& Wang, G.-X. 2013. In vivo anthelmintic effect of flavonol rhamnosides from Dryopteris crassirhizoma against Dactylogyrus intermedius in goldfish (Carassius auratus). Parasitol. Res., 112, 4097104.

Jiofack, T., Fokunang, C., Kemeuze, V., Fongnzossie, E., Tsabang, N., Nkuinkeu, R., Mapongmetsem, P. M. \& Nkongmeneck, B. A. 2008. Ethnobotany and phytopharmacopoea of the South-West ethnoecological region of Cameroon. J. Med. Plant Res, 2, 197-206.

Jouad, H., Haloui, M., Rhiouani, H., El-Hilaly, J. \& Eddouks, M. 2001. Ethnopharmacological survey of medicinal plants used for treatment of diabetes, cardiac and renal disease in the North Center region of Morocco J. Ethnopharmacol, 115, 175-182.

Kaneko, M. E. A. 1995. Allergen-specific lgG1 and lgG3 through Fc gamma RIl induce eosinophil degranulation. J Clin Invest, 95, 2813-21.

Karou, D., Dicko, M., Dsimpore, J. \& Traore, A. 2005. Antioxydant and antibacterial activities of polyphenols from ethnomedicinal plants of Burkina Faso. Afr. J. Biotechnol, 4, 150.

Karou, S., Tchacondo, T., Tchibozo, M., AbdoulRahaman, S., Anani, K., Koudouvo, K., Batawila, K., Agbonon, A., Simpore, J. \& De Souza, C. 2011. Ethnobotanical study of medicinal plants used in the management of diabetes mellitus and hypertension in the Central Region of Togo. Pharm Biol, 49, 12861297.

Katawa, G., Layland, L. E., Debrah, A. Y., Von Horn, C., Batsa, L., Kwarteng, A., Arriens, S., W. Taylor, D., Specht, S., Hoerauf, A. \& Adjobimey, T. 2015. Hyperreactive Onchocerciasis is Characterized by a Combination of Th17-Th2 Immune Responses and Reduced Regulatory $T$ Cells. PLOS Negl. Trop. Dis, 9, e3414.

Koba, K., Sanda, K., Raynaud, C., Guyon, C., Chaumont, J. \& Nicod, L. 2008. Chemical Composition and In Vitro Cytotoxic Activity of Xylopia aethiopica (Dun) A. Rich. (Annonaceae) Fruit Essential Oil from Togo. J. Essent. Oil Res, 20, 354-357.

Kokou, K., Tossou, G., Essou, J.-P., Batawila, K., Akoegninou, A. \& Akpagana, K. 2001. Biodiversité médicinale au sud du Togo. J. Rech. Sci. Univ. Bénin, 57.
Lienou, T., Etoa, F.-X., Nkegoum, B., Pieme, C. \& Dzeufiet, D. 2007. Acute and subacute toxicity of Aspilia africana leaves. Afr. J. Trad. Cam, 4, 127-134.

Maizels, R. M. \& Lawrence, R. A. 1991. Immunological tolerance: The key feature in human filariasis? Parasitol Today, 7, 271-276.

Obhakhan, J., Ozor, M. \& Obodo, B. 2014. Histological Effects of Xylopia aethiopica on the Kidney of Adult Wistar Rats. Int. J. Herb, 3.

Obodo, B., Iweka, F., Obhakhan, J., Dada, F., Festus, O., Onoyovwi, A., Maduagwuna, G. \& Okoye, C. 2013. Hepatic Potentials of Xylopia Aethiopica Leaves in Adult Wistar Rats. Int. J. Herb. Med, 2, 36 - 41.

OCDE 2001. Toxicité orale aiguë - Méthode par classe de toxicité aiguë. In Lignes directrice de l'OCDE pour les essais de produits chimiques $2001 \mathrm{~b}$. OCDE, Paris, 1, 1-14.

OCDE 2009 Études de toxicité chronique. In Lignes directrice de l'OCDE pour les essais de produits chimiques. OCDE, Paris, 1, 1-16.

Ogbonnia, S., Adekunle, A., Bosa, M. \& Enwuru, V. 2008. Evaluation of acute and subacute toxicity of Alstonia congensis Engler (Apocynaceae) bark and Xylopia aethiopica (Dunal) A. Rich (Annonaceae) fruits mixtures used in the treatment of diabetes. Afr. J. Biotechnol, 7, 701705.

Oloyede, A. \& Aduramigba-Modupe, A. 2011. Antimicrobial activities of crude ethanolic extract of Xylopia aethiopica. Int. J. Curr. Res, 3, 5-7

Onu, A., Saidu, Y., Ladan, M. J., Bilbis, L. S., Aliero, A. A. \& Sahabi, S. M. 2013. Effect of Aqueous Stem Bark Extract of <i>Khaya senegalensis</i> on Some Biochemical, Haematological, and Histopathological Parameters of Rats. J. Toxicol, 2013, 803835.

Pratt, D. S. \& Kaplan, M. M. 2000. Evaluation of Abnormal Liver-Enzyme Results in Asymptomatic Patients. N. Engl. J. Med, 342, 1266-1271.

Re, R., Pellegrini, N., Proteggente, A., Pannala, A., Yang, M. \& Rice-Evans, C. 1999. Antioxidant activity applying an improved ABTS radical cation decolorization assay. $\quad$ Free Radic. Biol. Med, 26, 1231-1237.

Ritter, M., Tamadaho, R. S., Feid, J., Vogel, W., Wiszniewsky, K., Perner, S., Hoerauf, A. \& Layland, L. E. 2017. IL-4/5 signalling plays an 
important role during Litomosoides sigmodontis infection, influencing both immune system regulation and tissue pathology in the thoracic cavity. Int J Parasitol, 47, 951-960.

Rout, S. P., Choudary, K., Kar, D., Das, L. \& Jain, A. 2009. Plants in traditional medicinal systemfuture source of new drugs. Int J Pharm Sci, 1.

Shakya, A. K. 2016. Medecinal plants: future source of new drugs. Int. J. Herb. Med, 4.

Sharma, R., Kumar, R., Mishra, A. \& Guupta, R. 2010. Problems associated with clinical trials of Ayurvedic medecines. Rev Bras Farmacogn, 20, 276-281.

Singleton, V. L., Orthofer, R. \& Lamuela-Raventos, R. M. 1999. Analysis of total phenols and other oxidation substrates and antioxidants by means of Folin-Ciocalteu reagent. Methods Enzymol, 299, 152-178.

Suleiman, M., Mamman, M., Aliu, Y. \& Ajanusi, J. 2005. Anthelmintic activity of the crude methanol extract of Xylopia aethiopica against Nippostrongylus brasiliensis in rats. Veterinarski Arhiv, 75, 487-95.

Taylor, M. J. 2003. Wolbachia in the inflammatory pathogenesis of human filariasis. Ann N Y Acad Sci, 990, 444-9.

Taylor, M. J., Hoerauf, A. \& Bockarie, M. 2010. Lymphatic filariasis and onchocerciasis. Lancet, 376, 1175-85.

Tchacondo, T. 2011. Herbal Remedies and Their Adverse Effects in Tem Tribe Traditional Medicine in Togo. Afr. J. Tradit. Complement. Altern. Med, 8, 45-60.

Tirzitis, G. \& Bartoz, G. 2010. Determination of antiradical and antioxidant activity: basic principles and new insights. Acta Biochimica Polonica, 57.

Toudji, G., Dosseh, K., Karou, S., Adjrah, Y., Anani, K., Ameyapoh, Y. \& Simpore, J. 2017 Acute and sub-acute toxicity of Pithecellobium dulce (Roxb.) Benth. stem bark hydroalcoholic extract on Wistar rats. J Pharm Pharmaco Res, 5, 310319.

Toudji, G., Thiombiano, E., Karou, S., Anani, K., Adjrah, Y., Gbekley, H., Kiendrebeogo, M., Ameyapoh, Y. \& Simpore, J. 2018. Antibacterial and AntiInflammatory Activities of Crude Extracts of three Togolese Medicinal Plants Against Esbl Klebsiella Pneumoniae Strains. Afr J Tradit Complement Altern Med, 15, 42-58.
Van Riet, E., Hartgers, F. C. \& Yazdanbakhsh, M. 2007. Chronic helminth infections induce immunomodulation: Consequences and mechanisms. Immunobiol, 212, 475-490.

Veeresham, C. 2012. Natural products derived from plants as source of drugs. J. Adv. Pharm. Technol. Res, 3.

Velázquez, R. F., Rodrı, X, Guez, M., Navascués, C. A., Linares, A., Pérez, R., Sotorrı, X, Os, N. G., Martı, X, Nez, I. \& Rodrigo, L. 2003. Prospective analysis of risk factors for hepatocellular carcinoma in patients with liver cirrhosis. Hepatology, 37, 520-527.

WHO 2012. Médecine traditionelle: des textes anciens aux nouveaux médicaments. Bull World Health Organ, 90, 557-632.

Wisastra, R. \& Dekker, F. J. 2014. Inflammation, Cancer and Oxidative Lipoxygenase Activity are Intimately Linked. Cancers, 6, 1500-1521.

Yakubu, M. T., Adebayo, O. J., Egwim, E. C. \& Owoyele, V. B. 2005. Increased liver alkaline phosphatase and aminotransferase activities following administration of ethanolic extract of Khaya senegalensis stem bark to rats. Nig Soc Exp Biology, 17. 